\title{
PENDAMPINGAN PEMBUATAN INTERACTIVE SMART TEST SECARA KREATIF DAN INOVATIF BERBASIS TIK
}

\author{
F. Shoufika Hilyana ${ }^{*}$, Muhammad Malik Hakim ${ }^{2}$ \\ ${ }^{1}$ Program studi PGSD, Fakultas Keguruan dan Ilmu Pendidikan, Universitas Muria Kudus \\ Gondangmanis Bae, Kudus \\ ${ }^{2}$ Program studi Teknik Informatika, Fakultas teknik, Universitas Muria Kudus \\ Gondangmanis Bae, Kudus \\ *Email: farah.hilyana@umk.ac.id
}

\begin{abstract}
Abstrak
Ujian akhir semester selama ini merupakan salah satu momok yang menakutkan bagi para peserta didik. Hal ini terlihat dengan semakin meningkatnya tekanan (stress) yang dialami oleh para peserta didik menjelang dilaksanakannya ujian akhir semester di setiap sekolah. Peningkatan stress pada peserta didik ini menjadi salah satu penyebab tidak optimalnya nilai hasil ujian akhir semester para peserta didik yang berakibat lebih lanjut pada tidak optimalnya nilai prestasi belajar sehingga akan berpengaruh terhadap penerimaan peserta didik tersebut pada jenjang sekolah yang lebih tinggi. Untuk menurunkan tingkat stress ini, maka paradigma ujian akhir semester harus diubah agar ujian menjadi lebih menarik dan menyenangkan. Salah satu cara yang dapat dilakukan adalah dengan menerapkan Interactive and smart test yang direncanakan akan dilaksanakan sebagi program workshop dan pelatihan di MGMP IPA MTs di lingkungan LP Maarif Kudus. Smart test yang interaktif ini diharapkan menghilangkan ketakutan para peserta didik sehingga ujian akan menjadi lebih menarik dan menyenangkan dan pada gilirannya akan mampu meningkatkan nilai prestasi hasil belajar peserta didik. Dengan adanya penambahan dan peningkatan kemampuan ini bagi para guru dapat membuat smart test berbasis TIK secara mandiri baik secara offline maupun online.
\end{abstract}

Kata Kunci: Smart test, peserta didik, interactive test, ujian.

\section{PENDAHULUAN}

Perkembangan teknologi menuntut dunia pendidikan terus meningkatkan mutu penggunaan teknologi informasi dalam pembelajaran dengan tempat belajar dinamis berorientasi objek yang berbasis web (Sampurno et.al, 2015). Berbagai teknologi dan aplikasi pendukung telah dikembangkan sebagai upaya untuk mendukung dan mempermudah aktivitas kehidupan manusia dan organisasi, termasuk kegiatan belajar mengajar dalam dunia pendidikan. Peningkatan kualitas pendidikan terus diupayakan, salah satunya melalui pemanfaatan teknologi informasi dan komunikasi dalam upaya peningkatan mutu guru (Riyana, 2010).

Menurut Halidi, et.al (2015) menyatakan bahwa bentuk inovasi dalam pendidikan yang berkaitan dengan tujuan pembelajaran melalui pemanfaatan teknologi informatika sebagai upaya untuk membelajarkan siswa agar terjadi belajar secara optimal pada diri peserta didik untuk mengantisipasi arah perkembangan ilmu pengetahuan dan teknologi.

Seiring dengan dengan berkembangnya teknologi komputer pada saat ini, maka pemanfaatan Teknologi Informasi dan Komunikasi (TIK) atau ICT sangat dibutuhkan. Perkembangan TIK telah memberikan pengaruh yang sangat besar terhadap dunia pendidikan, khususnya dalam proses pembelajaran sampai proses evaluasi pendidikan. Model pembelajran berbasis TIK berpengaruh terhadap hasil belajar dan motivasi belajar siswa (Suratman et.al, 2019).

Pada kurikulum 2013 guru dan peserta didik dituntut bisa dan efektif dalam menggunakan Teknologi Komunikasi dan Informasi (TIK) tidak hanya dalam pembelajarannya, tetapi dalam evaluasi pembelajarannya. Evaluasi pembelajaran tidak lepas dari penggunaan instrument, salah satunya instrument yang diberikan berupa soal tes. Tes ini digunakan untuk mengukur sejauh mana seorang peserta didik telah menguasai pelajaran yang disampaikan. Tes merupakan suatu teknik atau cara yang digunakan dalam rangka melaksanakan kegiatan pengukuruan, yang didalamnya terdapat berbagai pertanyaan, pernyataan atau serangkaian tugas yang harus dikerjakan atau dijawab oleh peserta didik guna mengukur aspek perilaku peserta didik (Arifin, 2009). 
Setiap menjelang akhir semester, semua peserta didik di sekolah wajib mengikuti ujian akhir semester. Nilai hasil ujian akhir semester merupakan salah satu komponen utama evaluasi yang dilakukan oleh para guru terhadap peserta didik. Materi yang diujikan dalam ujian akhir semester pada umumnya diambilkan dari materi dari mata pelajaran yang diberikan sejak awal semester, sehingga materi ujian akhir semester cukup banyak. Hal ini berlaku untuk semua mata pelajaran yang diujikan, sehingga para peserta didik harus belajar dan berlatih dengan keras agar mendapatkan hasil maksimal dalam mengikuti ujian akhir semester di sekolahnya.

Sebagian besar peserta didik telah memahami bahwa ujian akhir semester merupakan event yang sangat penting bagi perkembangan prestasi belajarnya. Karena bobot hasil ujian akhir semester yang cukup besar, sehingga memiliki kontribusi yang sangat signifikan dalam nilai akhir semester yang akan tercantum dalam laporan hasil belajar di setiap semesternya. Laporan hasil belajar setiap semester ini lah yang akan menjadi dasar bagi pemberi beasiswa untuk memberikan beasiswa, melanjutkan, atau bahkan menghentikan beasiswa yang telah diterima oleh seorang peresta didik. Lebih dari itu, prestasi belajar yang terdapat dalam laporan hasil belajar siswa per semester tersebut harus dimonitor dengan baik, karena akan menjadi pertimbangan untuk menerima atau tidak menerima peserta didik di sekolah jenjang selanjutnya.

Hal ini membuat tingkat tekanan yang dialami oleh peserta didik di sekolah menengah cukup besar, karena bagi mereka event yang pada umumnya hanya berlangsung selama satu sampai dua minggu di akhir semester ini sangat menentukan bagi perkembangan prestasi belajar mereka (Arjanto, 2016). Tingkat stress yang cukup tinggi juga dirasakan oleh peserta didik di jenjang sekolah yang lebih tinggi, terutama di kelas XII (Kinantie, 2012). Beberapa guru pada umumnya bahkan telah melakukan beberapa evaluasi tambahan sebagai antisipasi untuk menghindari nilai yang kurang sebagai hasil ujian akhir semester yang tidak optimal. Tekanan demi tekanan tersebut membuat peserta didik sering merasa tidak nyaman ketika memasuki dan/atau menghadapi masa evaluasi atau ujian. Tekanan inilah dalam beberapa kasus justru menjadi penyebab tidak optimalnya (dan bahkan jatuhnya) nilai hasil ujian akhir semester.

Salah satu cara yang harus dilakukan untuk menurunkan tingkat tekanan (stress) peserta didik dalam menghadapi evaluasi dan/atau ujian adalah dengan membuat ujian menjadi hal yang tidak menakutkan, dan bahkan menyenangkan. Paradigma ujian yang menyenangkan perlu ditanamkan kepada peserta didik sejak awal keikutsertaan mereka dalam mengikuti aktivitas pembelajaran di sekolah. Hal ini dapat dilakukan dengan beberapa tahapan, yang antara lain adalah pembiasaan menghadapi ujian/evaluasi baik secara terjadwal maupun tidak terjadwal agar peserta didik selalu menyiapkan dirinya dengan belajar; melakukan simulasi atau latihan ujian yang dibuat seperti ujian akhir semester; dan membuat soal ujian secara interaktif dan menyenangkan agar peserta didik merasa nyaman dan tidak merasa takut dalam menghadapi dan mengikuti ujian.

Soal ujian yang dibuat secara interaktif, menarik dan menyenangkan akan membuat mereka yang mengikuti/mengerjakannya menjadi nyaman sehingga mampu menghilangkan rasa takut dan menurunkan tingkat tekanan/stress ke tingkat yang jauh lebih rendah. Dengan semakin menurunnya tingkat stress dan meningkatnya rasa nyaman dan menyenangkan, diharapkan peserta didik justru akan memiliki dorongan semangat untuk mengerjakan dan menyelesaikan soal - soal ujian yang diberikan secara optimal, yang pada gilirannya diharapkan akan mampu meningkatkan nilai hasil ujian mereka.

Smart test merupakan salah satu bentuk tes/ujian yang dibuat sedemikian rupa agar mampu menyesuaikan dengan orang yang mengerjakannya, disamping memberikan fitur interaktif yang user friendly sehingga yang mengerjakannya menjadi nyaman dan betah dalam mengerjakan soalsoal tes yang ada. Smart test hanya dapat dibuat berbasis TIK, karena dalam pembuatannya diperlukan adanya tampilan yang menarik dan inovatif untuk menghindari kesan monoton yang membosankan. Lebih lanjut, smart test memungkinkan adanya ragam variasi bentuk soal, sehingga tidak terlalu terlihat adanya dikotomi bentuk soal seperti soal pilihan ganda, soal essay, isian singkat, dan lain-lain.

MGMP IPA MTs LP Ma'arif Kudus merupakan paguyuban guru IPA tingkat MTs yang dikelola oleh LP Maarif Kabupaten Kudus. Dalam menjalankan aktivitas ujian akhir semester, para guru masih menerapkan metode ujian dan evaluasi secara konvensional yang berakibat pada peningkatan tingkat stress yang dialami oleh peserta didik dalam menghadapi ujian akhir semester, yang berdampak pada kurang optimalnya nilai hasil belajar peserta didik. Para guru mengharapkan 
adanya solusi yang mampu membuat para siswa merasa nyaman dalam mengikuti ujian akhir semester, dimana kenyamanan dalam mengerjakan ujian akan berdampak pada peningkatan nilai hasil belajar di akhir semester.

Usulan program pengabdian ini, yaitu berupa pelatihan, workshop dan pendampingan dalam membuat Smart Test yang interaktif diharapkan mampu memberikan solusi alternatif bagi para guru IPA di MGMP IPA LP Ma'arif Kudus dalam menurunkan tingkat stress peserta didik dalam menghadapi dan mengikuti ujian akhir semester. Pelatihan ini sekaligus diharapkan berhasil meningkatkan kompetensi dan keahlian guru dalam melaksanakan KBM yang inovatif, kreatif, dan menyenangkan sehingga dapat memberikan kontribusi dalam meningkatkan prestasi belajar peserta didik di sekolah.

Tujuan pelaksanaan pengabdian masyarakat ini adalah memberikan pengetahuan bahwa tes berbasis TIK dapat dilakukan secara mudah dan praktis serta mampu meningkatkan ketertarikan dari peserta didik, dan memberikan pelatihan dan simulasi pembuatan soal tes yang interaktif dan menyenangkan berbasis TIK. Manfaat pelaksanaan kegiatan pengabdian ini antara lain: Meningkatkan pemahaman bagi guru bahwa test atau ujian dapat diubah menjadi hal yang tidak menakutkan dan bahkan menyenangkan; dan Adanya penambahan dan peningkatan kemampuan bagi para guru untuk membuat smart test berbasis TIK secara mandiri.

\section{METODE}

Bentuk realisasi pemecahan masalah dalam pengabdian ini adalah dengan melakukan pelatihan dan workshop pembuatan smartest yang interaktif dan menyenangkan berbasis TIK. Pelatihan dan workshop ini diikuti oleh perwakilan dari para guru anggota MGMP IPA di lingkungan LP Ma'arif Kabupaten Kudus.

Materi pelatihan dan workshop yang diberikan meliputi :

1. Pembuatan tes sehingga menjadi hal yang menyenangkan bagi peserta didik

2. Pengenalan dan Pembuatan interactive smart test.

3. Pengisian dan Pengaturan penilaian interactive smarttest berbasis TIK secara offline dan online.

Metode yang dipergunakan dalam pengabdian ini adalah paparan materi dan FGD (focus group discussion), pelatihan dan workshop, dan dilanjutkan dengan praktek secara langsung menggunakan komputer yang dihubungkan secara daring ke internet. Waktu pelaksanaan kegiatan dilaksanakan selama dua hari yaitu tanggal 30 - 31 Januari 2020. Dan bertempat di Laboratorium Teknik Informatika Universitas Muria Kudus.

\section{HASIL DAN PEMBAHASAN}

Pelaksanaan kegiatan pengabdian masyarakat dalam bentuk pelatihan dan workshop pelatihan, workshop dan pendampingan dalam membuat Smart Test yang interaktif diharapkan mampu memberikan solusi alternatif bagi para guru IPA di MGMP IPA LP Ma'arif Kudus ini telah dilaksanakan sesuai dengan rencana dan jadwal yang telah disusun. Dalam kegiatan ini telah dilaksanakan serangkaian kegiatan yang terdiri dari paparan yang dilanjutkan dengan FGD (Focus Group Discussion) pada hari pertama, dan praktek serta workshop pembuatan, pengisian, dan pengaturan interactive smart test pada hari selanjutnya. Para guru yang menjadi peserta telah berhasil membuat interactive smart test secara mandiri, baik secara offline maupun online yang kemudian disebarkan kepada anak didik. Selanjutnya, para peserta telah mengetahui cara melakukan pengaturan interactive smart test agar dapat menurunkan tingkat stress menghadapi ujian dan selalu menarik bagi anak didik.

Kegiatan ini diikuti oleh 8 orang Guru IPA yang merupakan anggota MGMP IPA MTS di lingkungan LP Ma'arif Kabupaten Kudus. Dari hasil pelatihan dan evaluasi, diketahui bahwa para guru telah merasakan manfaat dan kemudahan dalam pembuatan interactive smart test berbasis TIK dalam proses pembelajaran. Dengan adanya pemanfaatan TIK ini, para guru dapat memberikan tambahan pengalaman dalam pembuatan interactive smart test yang menarik dan dapat membantu memberikan pemahaman kepada para anak didik. Selain itu, para guru juga dapat memberikan informasi nilai secara real dan jujur yang dapat ditujukan kepada anak didik sehingga dapat meningkatkan karakter anak untuk bersikap jujur, tanggung jawab serta disiplin karena dalam 
penyelesaian interactive smart test ini menggunakan alokasi waktu yang telah ditentukan oleh pembuat interactive smart test (guru).

Pelatihan ini berhasil meningkatkan kompetensi dan keahlian guru dalam melaksanakan KBM yang inovatif, kreatif, dan menyenangkan sehingga dapat memberikan kontribusi dalam meningkatkan prestasi belajar peserta didik di sekolah. Penerapan TIK dalam proses pembelajaran ini dilakukan untuk menurunkan tingkat stress peserta didik dalam menghadapi dan mengikuti ujian akhir semester. Hal ini juga dapat meningkatkan pemahaman bagi guru bahwa test atau ujian dapat diubah menjadi hal yang tidak menakutkan dan bahkan menyenangkan. Dengan adanya penambahan dan peningkatan kemampuan ini bagi para guru dapat membuat smart test berbasis TIK secara mandiri baik secara offline maupun online.

\section{KESIMPULAN}

Serangkaian pelaksanaan pengabdian ini telah berhasil meningkatkan kompetensi dan keahlian guru dalam melaksanakan KBM yang inovatif, kreatif, dan menyenangkan sehingga dapat memberikan kontribusi dalam meningkatkan prestasi belajar peserta didik di sekolah. Melalui penerapan TIK, para siswa akan mampu menurunkan tingkat stress peserta didik dalam menghadapi dan mengikuti ujian akhir semester. Manfaat nyata yang diperoleh oleh guru adalah meningkatkan pemahaman bagi guru bahwa test atau ujian dapat diubah menjadi hal yang tidak menakutkan dan bahkan menyenangkan. Dengan adanya penambahan dan peningkatan kemampuan ini bagi para guru dapat membuat smart test berbasis TIK secara mandiri baik secara offline maupun online.

\section{DAFTAR PUSTAKA}

Arifin, Z. 2009. Evaluasi Pembelajaran. PT Remaja Rosdakarya Offset. Bandung.

Arjanto, P. 2016. Identifikasi Tingkat Stres Peserta Didik Menjelang Ujian Nasional Pada Jenjang Pendidikan Menengah. Jurnal Konseling Indonesia, 1(2) : 96 - 100.

Halidi, H. M., Husain, S. N., Saehana, S. 2015. Pengaruh Media Pembelajaran Berbasis TIK terhadap Motivasi dan Hasil Belajar IPA Siswa Kelas V SDN Model Terpadu Madani Palu. e-Jurnal Mitra Sains, 3 (1) : 53-60.

Kinantie, O. A. 2012. Gambaran Tingkat Stres Siswa SMAN 3 Bandung Kelas XII Menjelang Ujian Nasional 2012. Students e-Journal, 1 (1) : 1 - 14.

Riyana, Cepi. 2010. Peningakatan Kompetensi Pedagogis Guru Melalui Penerapan Model Education Centre Of Teacher Interactive Virtual (Educative). Jurnal Penelitian Pendidikan. Vol. 11 (1).

Sampurno, P.J., Maulidiyah, R., dan Puspitaningrum, H.Z. 2015. Implementasi Kurikulum 2013: MOODLE (Modular Object Oriented Dynamic Learning Environment) dalam Pembelajaran Fisika melalui Lembar Kerja Siswa pada Materi Optik di SMA. Jurnal Fisika Indonesia. XIX (55) : 54-58.

Suratman, A., Rakhmasari, R., Apyaman, D. 2019. Pengaruh Model Pembelajaran Berbasis TIK Terhadap Hasil Belajar Matematika dan Motivasi Belajar Matematika. Jurnal Analisa. 5 (1): 41-50. 